\title{
Expression of Mesenchymal Stem Cell Phenotype in Human Nasal Respiratory Epithelial Cells
}

\author{
Expresión del Fenotipo de Células Troncales Mesenquimales \\ en Células Epiteliales Nasales Humanas
}

Aisha A. Muhammed",**; Mohd Heikal M. Yunus, ${ }^{*, * *}$; Aminuddin B. Saim, ${ }^{*, * * *}$ \& Ruszymah B. H. Idrus,***

MUHAMMED, A. A.; YUNUS, M. H. M.; SAIM, A. B. \& IDRUS, R. B. H. Expression of mesenchymal stem cell phenotype in human nasal respiratory epithelial cells. Int. J. Morphol., 33(4):1476-1482, 2015.

SUMMARY: The respiratory epithelium is the first line of contact with the external hazards. Thus it can be damaged and need to be replaced to avoid healing by fibrosis. Tracheal tissue engineering is an alternative promising treatment modality. Mesenchymal stem cell markers are surface proteins, which are responsible for some of these cells unique properties. The objective of this study was to detect the mesenchymal stem cell phenotype among the human nasal respiratory epithelial cells via two immunophenotyping techniques. Respiratory epithelial cells were cultured using co-culture technique, fibroblasts was removed at confluence leaving respiratory epithelial cells, which were passage further to passage 4. Cells were evaluated for mesenchymal stem cell markers that were CD73, CD90, CD105 and the hematopoietic stem cell marker CD45 at passage 1 (P1) and passage 4 (P4) using Flow cytometry and Immunocytochemistry techniques. Respiratory epithelial cells expressed the mesenchymal stem cell markers at P1 and maintain the expression these markers until P4. Using both techniques, to compare the values of mesenchymal stem cell markers expression at P1 to P4 there was no significant difference. This study indicates that respiratory epithelial cells derived from nasal turbinate retain some of mesenchymal stem cells properties even after serial passages. Both methods of Immunophenotyping are comparable.

KEY WORDS : Human nasal respiratory epithelium; Immunostaining; Mesenchymal stem cells marker; Tissue engineering; Nasal turbinate.

\section{INTRODUCTION}

The human respiratory tract is lined by a continuous layer of pseudostratified ciliated columnar epithelium known as respiratory epithelium or airway epithelium. It composed of many cell types mainly: columnar ciliated, goblet (mucus secreted cells) and basal cells. Respiratory epithelial cells (RE) perform many important functions. The most important function is the defense function. Respiratory mucosa is well adapted to perform the protection function. However, it still can be injured due to many causes, which range from mechanical injury to irritation due to chemical irritants or infectious agents (Dominici et al., 2006). The response to injury is very fast and starts within minutes after the injury (Knight \& Holgate, 2003). However, if the injury is widespread this natural repair mechanism is not enough for wound repair and fibrous tissue will replace the normal respiratory mucosa. Poor healing process in cases of large epithelial defect may results in fibrosis which subsequently cause tracheal stenosis (Mohd Heikal et al., 2010). Tissue engineering has drawn the attention as an emerging field that combines the engineering principles and life science (Langer \& Vacanti, 1993). Early tissue engineered tracheal models were constructed using chondrocytes and scaffold to produce tubular cartilage tissue. However, the use of these models in animal studies gave poor results due to the absence of the lining respiratory epithelium (Tan et al., 2006). The presences of respiratory epithelial cells lining provides faster wound healing and minimum fibrosis in compare with non cellular constructs (Mohd Heikal et al.). Human nasal turbinate, which is discarding during turbinectomy, is an accessible source for human respiratory epithelium.

Mesenchymal stem cells are commonly used as cell source in tissue engineering. This is because they possess the unique ability of differentiation into different specialized cells as well as the ability of self-renewal. The expression of the CD73, CD90 and CD105 proteins is one of the

\footnotetext{
* Department of Physiology, Faculty of Medicine, Universiti Kebangsaan Malaysia Medical Centre, Kuala Lumpur, Malaysia.

** Tissue Engineering Centre, Universiti Kebangsaan Malaysia Medical Centre, Kuala Lumpur, Malaysia.

**** Ampang Puteri Specialist Hospital, Selangor, Malaysia.
} 
essential criteria required for mesenchymal stem cells identification (Dominici et al.). These proteins have been identified to play roles in the mesenchymal stem cells differentiation, migration, cell-cell interactions and immunity adaption (Boxall \& Jones, 2012). The expression of these proteins (mesenchymal stem cell markers) by respiratory epithelium cells might indicate that these cells possess mesenchymal stem cells properties. Cells with stem cells properties can be considered as a good cell source in tissue engineered constructs. However, in order to get enough cells to make respiratory epithelium construct, the respiratory epithelium cells need to culture for few passages. The quality of the cells produced after serial passages need to be maintained. The aim of this study was to evaluate the expression level of the mesenchymal stem cell markers CD73, CD90, CD105 and the hematopoietic stem cell marker, CD45 at passage 1 and 4 in human respiratory epithelial cells using flow cytometry and immunocytochemistry analysis.

\section{MATERIAL AND METHOD}

Sample processing and cell culturing. Nasal turbinate tissue was obtained from the tissue discarded after turbinatectomy surgery. The use of human nasal turbinate has been approved by the Research and Ethics Committee of Medical Faculty, Universiti Kebangsaan Malaysia (ref. no.UKM 1.5.3.5/244/SPP3).

Six nasal turbinate samples were collected under aseptic condition. The samples were washed 3 times with Phosphate Buffered Saline (PBS) (Mediatech, USA) supplemented with Penicillin and Streptomycin. The mucosal layer was separated from the underlying bones and minced to $2 \mathrm{~mm}^{3}$ pieces to hasten the digestion process. The minced tissue was kept in a $50 \mathrm{ml}$ tube (BD Falcon, USA) then digested by adding $10 \mathrm{ml} 0.3 \%$ Collagenase type 1 (Gibco,USA) for 4-6 h in shaker incubator (Jouan,Guguay Trouin, SH) at $37{ }^{\circ} \mathrm{C}$. After complete digestion of the sample the suspension was filtered in a 50 $\mathrm{ml}$ tube using a cell strainer of $100 \mu \mathrm{m}$ (BD Falcon, USA) to get rid of undigested parts. The filtered suspension was centrifuged at $6500 \mathrm{rpm}$ for $5 \mathrm{~min}$ at $37{ }^{\circ} \mathrm{C}$ (Jouan centrifuge, Duguay Trouin, St. Herblain, France). The pellet (fibroblasts and respiratory epithelial cells) was washed twice to get rid of red blood cells. To separate the cells into single cell $10 \mathrm{ml}$ of Trypsin EDTA (Sigma-aldrich) was added to the pellet kept for $5 \mathrm{~min}$ at $37^{\circ} \mathrm{C}$. The action of trypsin was inhibited by adding $10 \mathrm{ml}$ of Trypsin Inhibitor (Gibco, USA) then the cell suspension was centrifuged for $5 \mathrm{~min}$ at $6500 \mathrm{rpm}$. The cells pellet washed 3 times using
PBS to get rid of the trypsin. The cells pellet suspended in Defined Keratinocytes Serum Free Medium (DKSFM) (Gibco, USA), F-12 (Gibco, USA), and Dulbecco's Modified Eagle's Medium (DMEM) (Gibco, USA) with ratio of 2:1:1, supplemented with 5\% Foetal Bovine Serum (Gibco, USA) [DKSFM:F-12:DMEM+5\%FBS] as described by Noruddin et al. (2007), and seeded in 6 well plates. The plate was incubated at $37^{\circ} \mathrm{C}$ in humid air with $5 \% \mathrm{CO}_{2}$ incubator (Jouan). An inverted light microscope (Olympus, Shinjuku-ku, Tokyo, Japan) was used for daily observation of the fibroblasts and respiratory epithelium cells. Once the respiratory epithelium cells and fibroblasts reached confluence, the fibroblast was then removed by adding $2 \mathrm{ml}$ of $0.05 \%$ trypsin EDTA solution for each well. The plate was kept for $2-3 \mathrm{~min}$ at $37^{\circ} \mathrm{C}$. Two milliliters of Trypsin Inhibitor was added per well to inhibit Trypsin EDTA action. The detached cells were then removed leaving colonies of respiratory epithelium cells. The respiratory epithelium colonies were washed with PBS supplemented with $1 \%$ of penicillin and streptomycin two times for 5 $\mathrm{min}$. Two milliliters of DKSFM was added for each well and the plate was kept at $37^{\circ} \mathrm{C}$ in a humidified $5 \% \mathrm{CO}_{2}$ incubator.

Flow cytometry analysis. Cells for flow cytometry were harvested from passage one and passage four. The cells were trypsinized as mentioned before by using 0.05 trypsinEDTA solution. The cells were washed using PBS then centrifuged at $5600 \mathrm{rpm}$ at $37^{\circ} \mathrm{C}$ for 5 min then counted using the previously mentioned protocol to get the appropriate cells number for this test. Cell suspension was aliquoted in four $15 \mathrm{ml}$ test tubes with $20 \times 10^{4}$ cells per tube. The cells in each tube were washed three times using sheath fluid $+1 \%$ FBS. The cells suspension in the four tubes was centrifuged at $5600 \mathrm{rpm}$ at $37^{\circ} \mathrm{C}$ for $5 \mathrm{~min}$. The cells were blocked using $1 \%$ rabbit serum and kept for 30 $\mathrm{min}$ at the room temperature to block the unspecific receptors. The cells then was washed using sheath fluid $+1 \% \mathrm{FBS}$ and centrifuged at $5600 \mathrm{rpm}$ at $37^{\circ} \mathrm{C}$. Twenty $\mu \mathrm{l}$ of the following monoclonal florescence conjugated antibodies CD73 (conjugated with PE), CD90 (conjugated with FITC), CD105 (conjugated with PE) and CD45 (conjugated with perCP) (all from BD Biosciences) were added separately to the four tubes (one antibody for each test tube). The tubes were wrapped with foil to prevent light exposure. The tubes were incubated for $30 \mathrm{~min}$ at room temperature. After $30 \mathrm{~min}$ the cells in each tube were washed twice using $1 \mathrm{ml}$ of sheath fluid $+1 \% \mathrm{FBS}$ to remove weakly or non-specifically bound antibodies and centrifuged for $5 \mathrm{~min}$ at $5600 \mathrm{rpm}$. The cell pellet was suspended into $1 \mathrm{ml}$ of PBS. The cell suspensions were filtered into the flow tubes using $100 \mu \mathrm{l}$ cell strainers to filter the clumped cells. The tubes kept in a cold box before the analysis. Number of events sat at ten thousand. 
Immunocytochemistry staining. Monolayer culture of respiratory epithelial cells from passage one and passage four were stained to detect the presence of the following markers CD73 (PE), CD90 (FITC), CD105 (PE) and CD45 (peRCP).

Cells were trypsinized and counted as described earlier; $5 \times 10^{4}$ respiratory epithelial cells were aliquoted into fifteen millilitres tube then were washed three times using PBS to get rid of trypsin. The respiratory epithelial cells were cultured in 8 wells chamber slide with cover glass slide (Thermo Scientific, Nuc Lab-Tek). The respiratory epithelial cells then were seeded in the five wells of the slide chamber at a density of $1 \times 104$ per well (each well $=0.8 \mathrm{~cm}^{2}$ ). Two hundreds $\mu 1$ of DKSFM was added for each well. The chamber slide was kept at $37{ }^{\circ} \mathrm{C}$ in a humidified $5 \% \mathrm{CO}_{2}$ incubator overnight. Next day cells were examined under the light microscope to check cell attachment. The cells usually attached after twenty four hours. The culture medium was discarded and the respiratory epithelial cells were washed twice using Two hundreds $\mu$ I PBS to wash each well. Cells then were fixed using 4\% paraformaldehyde solution (cross-linking fixative) in PBS and kept at $4{ }^{\circ} \mathrm{C}$ for one hour. The cells then were washed twice using two hundreds $\mu 1$ of ice cold PBS for five min. The next step was blocking the nonspecific surface receptors by the blocking solution which consists of $10 \%$ rabbit serum in PBS. Two hundreds $\mu 1$ of the blocking solution was added per well. The 8 well chamber slide kept at room temperature for $30 \mathrm{~min}$. The blocking solution was aspirated out and the respiratory epithelium cells were washed twice for five minutes using washing solution (1\% rabbit serum+ $0.1 \%$ Tween 20 diluted in PBS). Each of the monoclonal conjugated antibodies (CD73, CD90, CD105 and CD45) was diluted using antibody dilution solution (1\% rabbit serum in PBS). Antibodies were diluted to concentration of 1:20 using the antibody dilution solution. Two hundreds $\mu$ l of each diluted antibody was added to each well and one well was used as a control. The chamber slide was incubated at $4{ }^{\circ} \mathrm{C}$ away from light for overnight. Next day, the chamber slide viewed under the light microscope to check the respiratory epithelial cells. The antibody solution was sucked out. Respiratory epithelial cells were washed three times for $5 \mathrm{~min}$ using $200 \mu \mathrm{l}$ of washing solution. The washing solution was discarded and the respiratory epithelial nuclei were stained with $200 \mu \mathrm{l}$ freshly prepared DAPI (4',6diamidino-2-phenylindole) stain solution diluted in PBS (1:20000) per well. DAPI is a fluorescent stain that binds strongly to A-T rich regions in DNA. The chamber slide was kept away from light at room temperature for 15 minutes. The DAPI solution was then discarded and each well was washed three times for $5 \mathrm{~min}$ with PBS. The surface was mounted with one drop of PBS and covered with cover glass. The slide was wrapped with foil to protect the photosensitive fluorescence antibodies from light. The slide was viewed under confocal microscope in the dark.

Statistical analysis. The differences between passage 1 and 4 for each mesenchymal and hematopoietic stem cell marker at passage 1 and 4 of human respiratory epithelial cells were analyzed using the Mann-Whitney test. $\mathrm{p}<0.05$ was taken to indicate statistical significance. Statistical analysis was performed using SPSS 14.

\section{RESULTS}

The respiratory epithelium cells were expanded forming more colonies and the gaps left were filled by fibroblast cells (Fig. 1A). The respiratory epithelium cells were irregular polygonal in shape and some were oval in shape this is because of the fact that respiratory epithelial consists of many cell types 2 (Fig. 1B).

Flowcytometry analysis. Flowcytometry analysis shows that respiratory epithelial cells at passage 1 express the mesenchymal stem cell markers CD73, CD90 and CD105 (Fig. 2). Respiratory epithelial cells from passage 4 maintain the expression of those markers (Fig. 3). The level of the positive respiratory epithelial cells between the cells from passage 1 and 4, statistically shows no significant difference (Table I). The haematopoietic stem cell marker CD45 was expressed in low level in the respiratory epithelial cells from passage 1. However, the level of positive cells from passage 4 was higher and the difference was not significant.

Immunocytochemical analysis. Respiratory epithelial cells from passage 1 were positive for the mesenchymal stem cell antibodies CD73, CD90 and CD105. Respiratory epithelial cells from passage 4 were positive for those antibodies. However there was no significant difference statistically between $\mathrm{p} 1$ and $\mathrm{p} 4$ (Table II). Few cells from passage 1 expressed the haematopoietic stem cell marker CD45. However, the expression of the haematopoietic stem cell marker CD45 was significantly higher at passage 4 in compare with passage 1. Data shown in Table II for both passages. Figure 4A, B, C and D for passage 1 and Figure 4E, F, G and $\mathrm{H}$ for passage 4 .

\section{DISCUSSION}

Tracheal stenosis can happened as a sequence of respiratory mucosal injury. It can cause morbidity and mortality. There are many treatment modalities to treat 


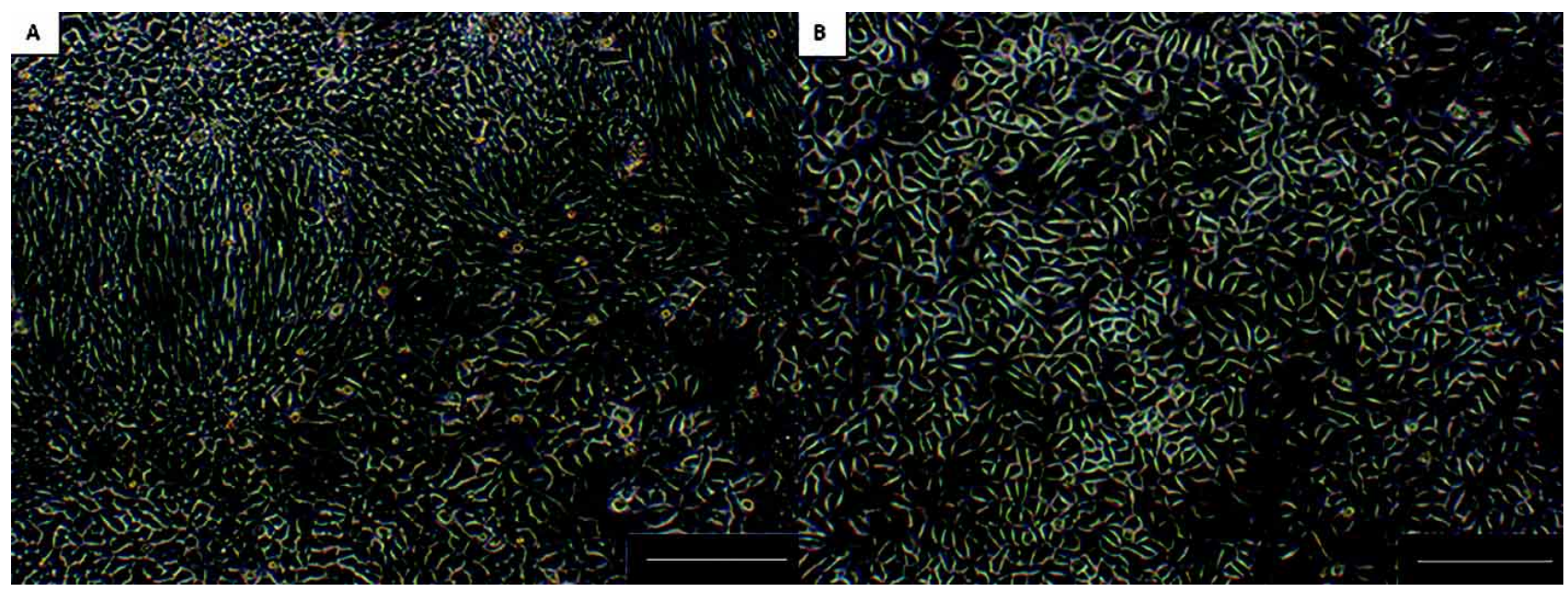

Fig. 1. A. Confluent respiratory epithelium and fibroblast co-culture (x40). Respiratory epithelial cells appear as irregular polygonal in shape. Fibroblasts (spindle shape) grow to fill the spaces between the respiratory epithelium colonies. B. The respiratory epithelial cells (x40) after removing fibroblasts at passage $1(\mathrm{Bar}=50 \mu \mathrm{m})$.
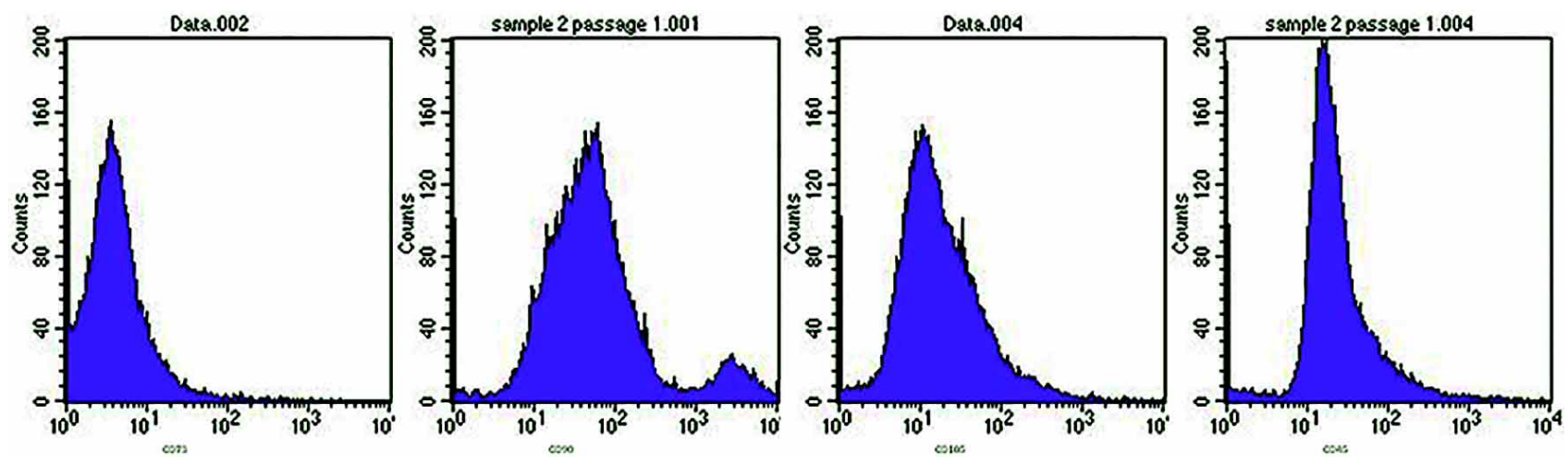

Fig. 2. Flowcytometry histogram shows the expression of the mesenchymal stem cell markers (CD73, CD90, CD105) and hematopoietic stem cell markers (CD45) in human nasal respiratory epithelial cells at passage 1.
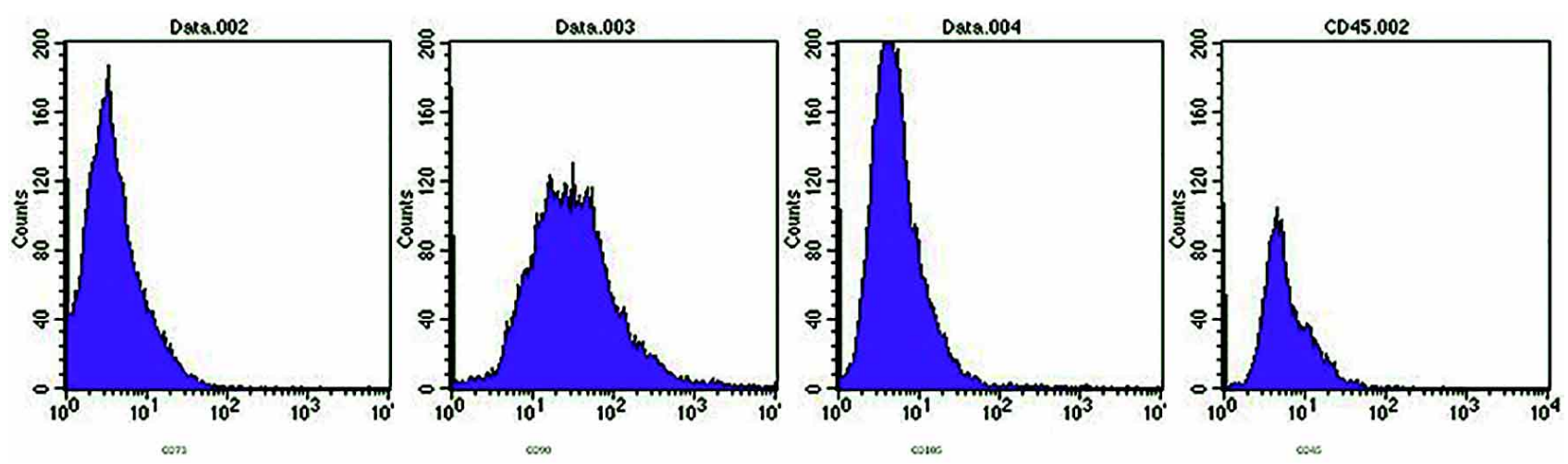

Fig. 3. Flowcytometry histogram shows the expression of the mesenchymal stem cell markers (CD73, CD90, CD105) and hematopoietic stem cell markers (CD45) in human nasal respiratory epithelial cells at passage 4. 

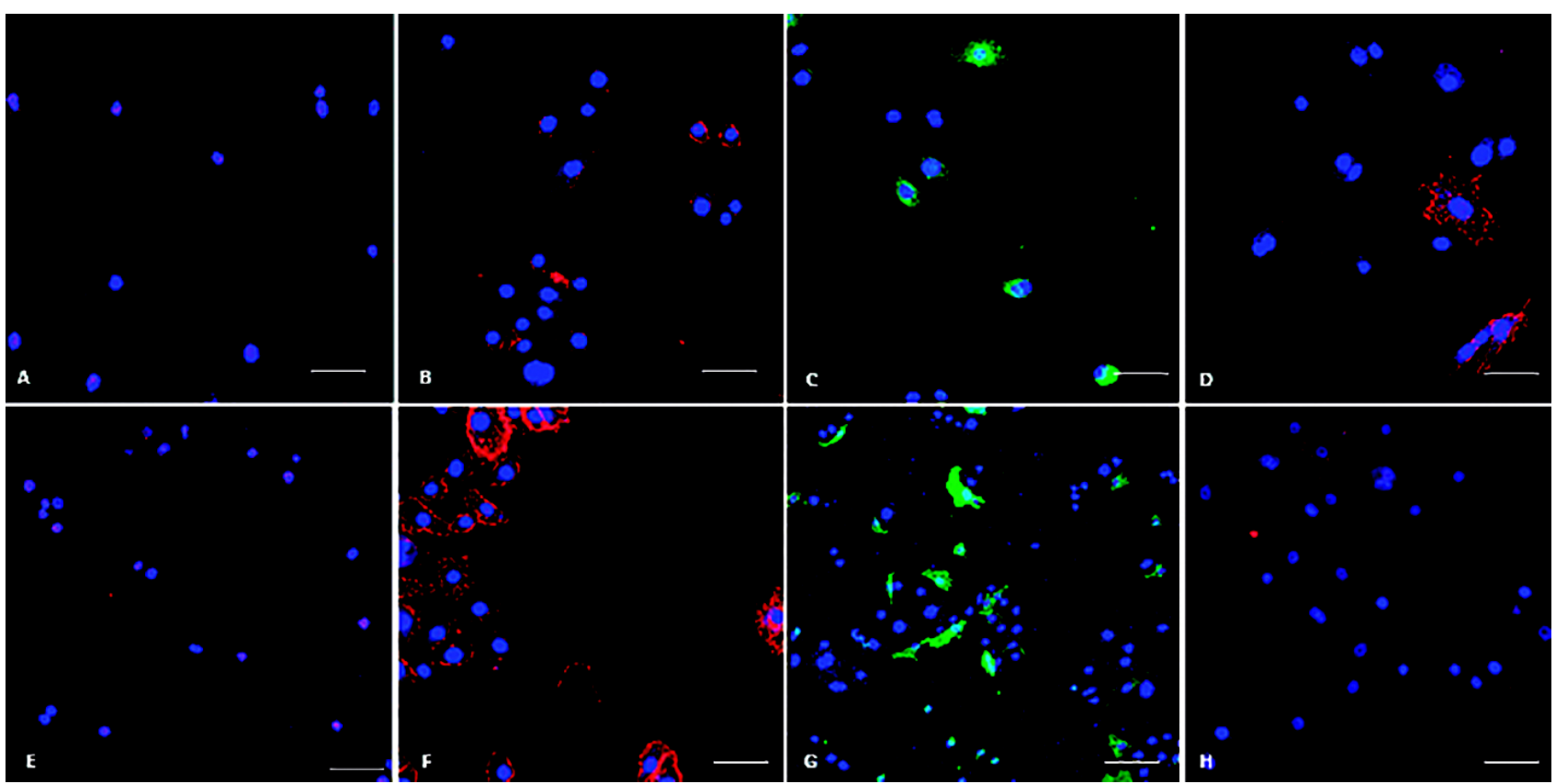

Fig. 4. B, C, D shows the respiratory epithelium cells at passage 1 and F, G, H at passage 4 were stained positive with mesenchymal stem cell antibodies CD73 (PE) orange, CD90 (FITC) green and CD105 (PE) orange respectively. A shows respiratory epithelium cells at passage 1 was negative however E shows the respiratory epithelium cells at passage 4 was stained positive for the haematopoitic stem cell marker CD45 (PerCp) red (Scale bar $=100 \mu \mathrm{m})$.

Table I. The expression of mesenchymal and haematopoitic stem cell markers using flow cytometry at passage 1 and passage 4 of human nasal respiratory epithelial cells.

\begin{tabular}{|c|c|c|c|c|}
\hline $\begin{array}{l}\text { Stem } \\
\text { markers }\end{array}$ & cell & $\begin{array}{l}\text { Percentage } \\
\text { expression }\end{array}$ & $\begin{array}{l}\text { Percentage } \\
\text { expression }\end{array}$ & P-value \\
\hline CD73 & & $72.5(4.2)$ & $64.7(6.0)$ & 0.3 \\
\hline CD90 & & $69.2(7.4)$ & $72.0(1.7)$ & 0.7 \\
\hline CD105 & & $33.7(3.1)$ & $37.1(4.9)$ & 0.5 \\
\hline $\mathrm{CD} 45$ & & $7.3(3.9)$ & $13.3(1.5)$ & 0.1 \\
\hline
\end{tabular}

Comparison of the percentage values, median (interquartile range) of respiratory epithelial cells that expressed the mesenchymal stem cell markers CD73, CD90, CD105 and haemotopoitic stem cell marker CD45 using flow cytometry. The difference was significant between P1 and P4 ( $p<0.05)$.

tracheal stenosis resulting from mucosal defect. Each of these modalities has benefits and limitation (Epstein, 2005). Tissue engineering principles has been used to enhance the epithelial regeneration (Brichet et al., 1999). Complete reepithelialization of tracheal lesion is essential to produce functional tracheal substitute (Tan et al.). Precise understanding of cell biology and cell-to-cell interaction is very important for the success of TE respiratory mucosa (Saxena, 2005). The mucosa of the nasal turbinate is an accessible part of the respiratory epithelium in comparison to other respiratory system parts and it is similar to tracheal mucosa. Inferior nasal turbinectomy is a common surgical procedure which is done frequently by the Ear Nose Trachea
Table II. The expression of mesenchymal and haematopoitic stem cell markers using Immunocytochemistry at passage 1 and passage 4 of human nasal respiratory epithelial cells.

\begin{tabular}{|c|c|c|c|}
\hline $\begin{array}{ll}\text { Stem } & \text { cell } \\
\text { markers } & \end{array}$ & $\begin{array}{l}\text { Percentage } \\
\text { expression }\end{array}$ & $\begin{array}{l}\text { Percentage } \\
\text { expression }\end{array}$ & $P$-value \\
\hline CD73 & $54.8(4.4)$ & $56.7(7.5)$ & 0.8 \\
\hline CD90 & $40.0(4.4)$ & $34.1(2.9)$ & 0.2 \\
\hline CD105 & $26.8(1.4)$ & $23.5(1.3)$ & 0.1 \\
\hline $\mathrm{CD} 45$ & $1.0(0)$ & $6.5(1.8)$ & 0.01 \\
\hline
\end{tabular}

Comparison of the percentage values, median (interquartile range) of respiratory epithelial cells that expressed the mesenchymal stem cell markers CD73, CD90, CD105 and haemotopoitic stem cell marker CD45 using immunocytochemistry. The difference was significant between P1 and P4 ( $<<0.05)$.

surgeons to treat some disorders like nasal obstruction. It is a low risk surgery with good outcome. Our researchers have used the nasal turbinate as a source of airway respiratory epithelium and fibroblasts in many studies. These studies include both animal and human models (Mohd Heikal et al.; Ruszymah et al., 2011; Noruddin et al.). In this study, the co-culture technique was used to culture the human nasal respiratory epithelium. This technique was investigated by Noruddin et al. Fibroblast cells activate epithelial cell migration and proliferation through cytokines secretions (Noruddin et al.). In this study the human nasal respiratory epithelial cells expressed three important mesenchymal stem cell markers CD73, CD90 and CD105 at passage 1. That 
may indicate human nasal respiratory epithelial cells retain mesenchymal stem properties up to passage 4. Respiratory epithelial cells behave like mesenchymal stem cells during healing process of respiratory mucosa injury. This process involved three steps: dedifferentiation of the epithelial cells to flattened cells which migrate to the injured site, proliferation and redifferentiation (Soleas et al., 2012). Production of respiratory epithelium construct for large mucosal defect will need large numbers of respiratory epithelial cells, therefore the cells need to culture for few passages, therefore, it is important to study the properties of the cells after serial passages (Yamashita et al., 2007). Human respiratory epithelial cells were able to maintain the expression of these markers up to passage 4 although no significant difference, Noruddin et al., demonstrated that the human nasal respiratory epithelial cells produce significant gene expression levels after serial passages. Our researchers have shown that human nasal respiratory epithelial cells express the stem cell markers FZD-9 and BST-1 and maintain their expression up to P4 (Ruszymah et al.). The expression of the haematopoietic stem cell markers CD45 was relatively low at passage 1 but maintain even with low expression up to passage 4 with no significant difference via flow cytometry and immunocytochemistry. Two immunophenotyping techniques were used in this study. Both of these techniques gave significant results. The live cells are used for flow cytometry analysis while in immunocytochemistry the cells were dead due to cell fixation prior to staining. Direct labelled antibodies were used in this study to stain the cells in both techniques. However, better signal can be obtained using indirect antibodies due to signal amplification (Javois, 1999). Flow cytometer is more sensitive for surface antigens than immunocytochemistry (Willingham, 2010). Since both techniques gave significant results; either of them can be used to detect the stem cell markers in the human nasal respiratory epithelium.

\section{CONCLUSION}

This study shows that the human nasal respiratory epithelium cells express the mesenchymal stem cell markers CD73, CD90, CD105 at passage 1 and passage 4. This highlighted the mesenchymal stem cells properties retained by human nasal respiratory epithelium cells derived from nasal turbinate and cultured using co-culture method. The human nasal respiratory epithelial was cells able to maintain their mesenchymal stem cells properties after serial passages. Two immunophenotyping methods were used for the quantitative estimation of the stem cell markers expression; both techniques show significant results, which indicate that both techniques can be used for the detection of mesenchymal stem cell markers in the human nasal respiratory epithelium.

MUHAMMED, A. A.; YUNUS, M. H. M.; SAIM, A. B. \& IDRUS, R. B. H. Expresión del fenotipo de células troncales mesenquimales en células epiteliales nasales humanas. Int. J. Morphol., 33(4):1476-1482, 2015.

RESUMEN: El epitelio respiratorio es la primera línea de contacto con los peligros externos. Por lo tanto, puede ser dañado y necesita ser reemplazado para evitar uan cicatrización por fibrosis. La ingeniería de tejidos traqueales es una modalidad de tratamiento alternativo prometedora. Los marcadores de células troncales mesenquimales son proteínas de superficie, que son responsables de algunas propiedades únicas de estas células. El objetivo fue detectar el fenotipo de células troncales mesenquimales entre las células epiteliales respiratorias nasales humanas a través de dos técnicas de inmunofenotipaje. Fueron cultivadas las células epiteliales respiratorias utilizando la técnica de co-cultivo; los fibroblastos se eliminaron en la confluencia dejando solo células epiteliales respiratorias, resultantes de los 4 pasajes. Las células fueron evaluadas para encontrar marcadores de células troncales mesenquimales mediante CD73, CD90, CD105 y el marcador de células troncales hematopoyéticas CD45 en el paso 1 (P1) y el paso 4 (P4), usando citometría de flujo y técnicas de inmunocitoquímica. Las células epiteliales respiratorias expresaron los marcadores de células troncales mesenquimales en P1 y mantuvieron la expresión de estos marcadores hasta P4. No hubo diferencias significativas en el uso de ambas técnicas al comparar los valores de los marcadores de células troncales mesenquimales expresadas desde P1 a P4. Este estudio indica que las células epiteliales respiratorias derivadas de la concha nasal retienen algunas de las propiedades de células troncales mesenquimales, incluso después de pases seriados. Ambos métodos de inmunofenotipificación son comparables.

PALABRAS CLAVE: Epitelio respiratorio nasal humano; Inmunotinción; Marcadores de células troncales mesenquimales; Ingeniería de tejidos; Concha nasal.

\section{REFERENCES}

Boxall, S. A. \& Jones, E. Markers for characterization of bone marrow multipotential stromal cells. Stem Cells Int., 2012:975871, 2012.
Brichet, A.; Verkindre, C.; Dupont, J.; Carlier, M. L.; Darras, J.; Wurtz, A.; Ramon, P. \& Marquette, C. H. Multidisciplinary approach to management of postintubation tracheal stenoses. Eur. Respir. J., 13(4):888-93, 1999. 
Dominici, M.; Le Blanc, K.; Mueller, I.; Slaper-Cortenbach, I.; Marini, F.; Krause, D.; Deans, R.; Keating, A.; Prockop, Dj. \& Horwitz, E. Minimal criteria for defining multipotent mesenchymal stromal cells. The International Society for Cellular Therapy position statement. Cytotherapy, 8(4):3157, 2006.

Epstein, S. K. Late complications of tracheostomy. Respir. Care, 50(4):542-9, 2005.

Javois, L. C. Immunocytochemical Methods and Protocols. Volume 115. Totowa, Humana Press, 1999. pp.107-11.

Knight, D. A. \& Holgate, S. T. The airway epithelium: structural and functional properties in health and disease. Respirology, 8(4):432-46, 2003

Langer, R. \& Vacanti, J. P. Tissue engineering. Science, 260(5110):920-6, 1993.

Mohd Heikal, M. Y.; Aminuddin, B. S.; Jeevanan, J.; Chen, H. C.; Sharifah, S. H. \& Ruszymah, B. H. Autologous implantation of bilayered tissue engineered respiratory epithelium for tracheal mucosal regenesis in a sheep model. Cell Tissues Organs, 192(5):292-302, 2010.

Noruddin, N. A.; Saim, A. B.; Chua, K. H. \& Idrus, R. Human nasal conchas as aviable source of respiratory epithelium cells using co-culture system versus dispase dissociation technique. Laryngoscope, 117(12):2139-45, 2007.

Ruszymah, B. H.; Azrul Izham, B. A.; Mohd Heikal, M. Y.; Khor, S. F.; Fauzi, M. B. \& Aminuddin, B. S. Human respiratory epeithelial cells from nasal concha expressed stem cell genes even after serial passaging. Med. J. Malaysia, 66(5):440, 2011.

Saxena, A. Tissue Engineering: Present concepts and strategies. $J$. Indian Assoc. Pediatr. Surg., 10:14-9, 2005.

Soleas, J. P.; Paz, A.; Marcus, P.; McGuigan, A. \& Waddell, T. K. Engineering airway epithelium. J. Biomed. Biotechnol., 10:11$55,2012$.

Tan, Q.; Steiner, R.; Hoerstrup, S. P. \& Weder, W. Tissue-engineered trachea: History, problems and the future. Eur. J. Cardiothorac. Surg., 30(5):782-6, 2006.

Willingham, M. C. Fluorescence labeling of surface antigens of attached or suspended tissue-culture cells. Methods Mol. Biol., 588:143-51, 2010.

Yamashita, M.; Kanemaru, S.; Hirano, S.; Magrufov, A.; Tamaki, H.; Tamura, Y.; Kishimoto, M.; Omori, K.; Nakamura, T. \& Ito, J. Tracheal Regeneration after Partial Resection: A Tissue Engineering Approach. Laryngoscope, 117(3):497-502, 2007.
Correspondence to:

Dr. Mohd Heikal Mohd Yunus, MD, MMedSc. Tissue Engineering Centre Universiti Kebangsaan Malaysia Medical Centre

Kuala Lumpur

MALAYSIA

Email: mohdheikalyunus@yahoo.com

Received: 05-07-2015

Accepted: 05-10-2015 